\title{
Optimizing the virtual classroom: A case of intensive English course in the Next Normal
}

\author{
Chayaporn Kaoropthai \\ Mae Fah Luang university, 333 Moo 1 Thasud, Muang, Chiang Rai 57100, Thailand \\ chayaporn.kao@mfu.ac.th
}

\section{ARTICLE INFO}

Article history

Received 28 September 2021

Revised 17 November 2021

Accepted 9 December 2021

\section{Keywords}

instructional design

intensive English course

online learning

technology-integrated teaching

the Next Normal

\section{ABSTRACT}

Due to the COVID-19 pandemic, online learning has automatically become a normal practice of the "Next Normal". Intensive English is a compact three-week course offered to get first-year students ready for university study. Online learning was something new for both students and instructors. A key challenge in online learning was how to make virtual classroom as lively and interactive as possible. The aim of this study was thus to design an instructional program which integrated various technological tools and applications to optimize the virtual classroom. The 63 first-year students from two intact sections of Intensive English were used as participants of the study. A technology acceptance model (TAM) questionnaire (Davis, 1989; Hernandez, 2021) was adapted to assess the effectiveness of the instructional program. The results of the study revealed that all of the participants achieved the overall objective of the course and the target CEFR's A2 level. They found their online learning experience rewarding. They were satisfied with this online learning experience and were willing to participate in similar online learning in the future. Additionally, recommendations for further research were discussed.

This is an open access article under the CC-BY-SA license.

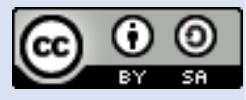

How to Cite: Kaoropthai, C. (2021). Optimizing the virtual classroom: A case of Intensive English course in the Next Normal. English Language Teaching Educational Journal, 4(3), 187-198.

\section{Introduction}

The COVID-19 pandemic has continued to disrupt the whole world. The diversification of the disease has brought about even more calamitous consequences in most areas. In education, all schools and universities had to change their delivery mode of instruction to exclusive online instruction. Compared with the on-site real classroom, the virtual classroom generally has a lot more disadvantages. In the virtual classroom, it is usually more difficult to control class, to keep students attentive and highly motivated, and to effectively promote collaborative and active learning. All school teachers as well as university instructors had to adapt themselves by learning, unlearning, and relearning to cope with the situations. One important way to maximizing the use of the fundamental learning platforms such as Google Meet, Microsoft Teams, WebEx, or Zoom, is to integrate additional technology tools and applications to support it. The problem faced by many teachers and instructors is how to utilize the platform to its optimum. The aim of this study is thus to develop an effective instructional program for the virtual classroom in the Next Normal. The program has been designed based on the ASSURE instructional development model (Heinich et al.,1989; Karakis et al.,2016; Sezer et al.,2013) and Connected Learning model (Ito et al., 2020). 


\subsection{Research questions}

1. To what extent can first-year students achieve the overall objective of the Intensive English course, based on the post-test scores and the total course score?

2. To what extent do first-year students accept the virtual classroom that integrates the use of supportive technological tools, based on the TAM?

\subsection{Instructional Design}

Instructional design (ID) is a power tool that helps instructors create effective learning experiences for learner. It is a process of taking classroom content and making it easy for learners to understand. ID has been further defined as "a process of solving instructional or educational problems through systematic analysis based on the conditions of learning" (Azimi \& Fazelian, 2013, p.256). ID has now become an essential component for designing online courses as instructors need an effective way to facilitate learners to actively involve as much as possible in the virtual classroom. The COVID-19 pandemic has accelerated the implementation of exclusive online learning worldwide. Many recent research studies (Baldwin \& Ching, 2020; Jusas el al., 2021; Nurpandi et al., 2013; Sanga, 2019; Zain, 2018) have focused on using ID models to develop effective online courses to meet the needs of students of the $21^{\text {st }}$ century. These studies have greatly contributed to the advancements of online instruction theories and practices that can be applied for online course designing in the pandemic situation.

ID models can be classified into three major categories: classroom-oriented, product-oriented, and system-oriented. Classroom-oriented ID models are used as a guideline to enhance the teaching and learning experiences in the classroom and are considered as potential models for designing technology-enhanced learning instruction (Lim \& Chai, 2008). ASSURE model (Heinich et al., 1989) and Kemp's model (Morrison et al., 2019) are examples of classroom-oriented ID models. Because this study aimed to develop an online Intensive English course, the ASSURE model has been adopted for course design.

\subsection{ASSURE Model}

ASSURE is a procedural, cyclic, and classroom-oriented ID model for designing and developing technology-integrated instruction (Bajacharya, 2019). The model was proposed by Heinich and colleagues in 1989. ASSURE is an acronym that stands for the six steps in the model as follows:

$$
\begin{array}{ll}
\text { A } & \text { Analyze learner } \\
\mathrm{S} & \text { State standards and objectives } \\
\mathrm{S} & \text { Select strategies, technology, media, and materials } \\
\mathrm{U} & \text { Utilize technology, media, and materials } \\
\mathrm{R} & \text { Require learner participation } \\
\mathrm{E} & \text { Evaluate and revise }
\end{array}
$$

These six steps of the ASSURE model thus involve how to analyze learners and state objectives, and to select, implement, and evaluate the technology and instructional resources for employing technology integration during classroom instruction to accomplish the learning objectives (Bajracharya, 2019, Heinich et al.,1989).

\subsection{Connected Learning}

Connected learning can be defined as "learning that connects personal interests, supportive relationships, and academic, civic, and career opportunity" (Ito et al, 2020, p.4). The relationship among these three elements of connected learning is illustrated in Fig. 1.

Connected learning is considered as "learning in an age of abundant access to information and social connection that embraces the diverse backgrounds and interests of all young people". Learning is motivating when it is related to personal interests. Interests keep learners attentive, make connections, persist and engage in deeper learning. In terms of relationships, it is evident that learners need support from peers and mentors when they encounter difficulties or challenges. Learners' accomplishments also depend on tangible connections to future real-world career and civic 
opportunities. According to Ito et al. (2020), connected learning originates when organizations sponsor and legitimize the interests of diverse youth, learners are engaged in shared practices such as creative production, research, or friendly competition; these practices are guided by shared purpose such as contributions to communities, social change, or solving real problems, and learning is connected across settings through brokering, coordination, and openly networked platforms (p.5).

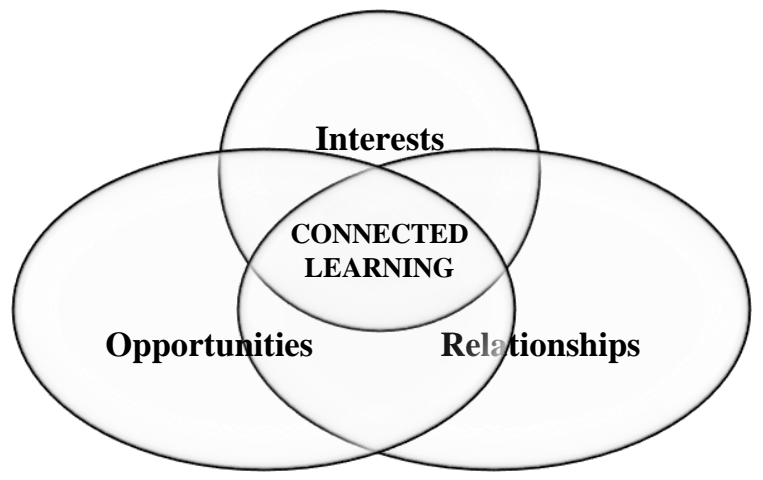

Fig. 1. Three spheres of learning that are integrated in connected learning (Ito et al, 2020, p.5).

\subsection{Networked Leaning}

Networked learning (NL) can be defined as learning in which information and communications technology (ICT) is employed to promote connections between learners, learners and teachers, learners and learning resources (Ahshan, 2021; Aljaafreh, 2021; Boonmoh et al., 2021; Wang et al., 2020). In language teaching, networked learning plays an important role in supporting learners to connect globally, access resources easily, and self-regulate their language processes (Boonmoh et al., 2021; Kannan \& Munday, 2018).

Networked technologies are an essential component of networked learning. Networked technologies in education include various types of social working such as online games, educational social network platforms, and popular general social network platforms (Johnson et al., 2016). In addition to networked devices such as desktop computer, laptops, tablets, and smartphone; technological applications are also considered as networked technologies. These applications include Padlet, Quizizz, Plickers, etc. They are designed to captivate and engage users for a particular purpose, including learning new knowledge, supporting classroom engagement, reviewing class content, building a positive learning atmosphere and improving learners' critical thinking skills (Boonmoh et al., 2021; Icard, 2014).

Table 1 lists some selected recent studies that examined technological tools used in English language teaching, complied by Boonmoh and colleagues (2021).

Table 1. Recent Studies Concerning the Use of Technological Tools in ELT

\begin{tabular}{ll}
\hline Author & Technological Tools \\
\hline Khamprem \& Boonmoh (2019) & Padlet, Kahoot, Quiziss, Plickers \\
Putri (2019) & Kahoot \\
Chaiyo \& Nokham (2017) & Kahoot, Quizizz, Google forms \\
Hwang et al. (2016) & Mobile game-based laerning \\
Dellos (2015) & Kahoot \\
DeWitt et al. (2015) & Padlet \\
Reinders \& Wattana (2015) & Gameplay \\
Wong et al. (2015) & 2D side-scrolling video game \\
\hline
\end{tabular}




\subsection{The context}

Intensive English course is a preparatory English course to prepare the first-year students whose ONET (Ordinary National Education Test) English scores are lower than 45\%, to get them ready for the study in an English-as-a-medium-of-instruction university. The brief details of the Intensive English course can be seen in the Appendix (see Appendix).

The course lasts 3 weeks: 3 hours daily, Monday to Friday, totaling 45 class hours, prior to the first semester regular courses. The researcher was the instructor who taught these two sections: one in the morning (9:00-12:00) and the other in the afternoon (13:00-16:00).

\section{Methodology}

\subsection{Participants}

The participants used in this study were a convenience sample. They were from two of the 85 sections of the first-year students who enrolled in Intensive English, prior to the beginning of the first semester of academic year 2021. These students were used as participants because the researcher was the instructor of these two sections. The students were from various schools of the university and varying English proficiency backgrounds.

Table 2. Distribution of Participants by University's Schools

\begin{tabular}{llcc}
\hline \multicolumn{1}{c}{ School } & No. of Students & $\%$ \\
\hline 1. & Cosmatic Science & 2 & 3.17 \\
2. & Health Science & 15 & 23.81 \\
3. & Information Technology & 14 & 22.22 \\
2. & Integrative Medicine & 1 & 1.59 \\
3. & Agro-Industry & 2 & 3.17 \\
4. & Sinology & 12 & 19.05 \\
5. & Management & 8 & 12.70 \\
6. & Law $\quad$ Total & 9 & 14.29 \\
& & 63 & 100 \\
\hline
\end{tabular}

Table 3. Distribution of Participants by English Proficiency Level

\begin{tabular}{ccc}
\hline English proficiency Level & No. of Students & \% \\
\hline Beginner & 38 & 60.32 \\
A1 & 15 & 23.81 \\
A2 & 8 & 12.70 \\
B1.2 & 2 & 3.17 \\
Total & $\mathbf{6 3}$ & $\mathbf{1 0 0}$ \\
\hline
\end{tabular}

Information in Table 2 and Table 3 shows that a majority of the participants (No.1-5 in Table $2=$ $53.96 \%$ ) were science students, while the other three groups $(45.04 \%)$ were from Sinology, Management, and Law. Most of the participants (60.32\%) were at the beginner level and the rest (39.68\%) were at the $\mathrm{A} 1$ to B1.1, of the CEFR.

\subsection{Instruments}

\section{TAM questionnaire}

A Technology Acceptance Model (TAM) questionnaire (Davis 1989; Hernandez, 2021; Weng et al., 2018) was developed to elicit information about students' perceived usefulness, perceived ease of use, student satisfaction, and intention to use. The questionnaire included 16 items, with four items for each component. The students were requested to complete the questionnaire on a five-point Likert scale, from 1 (strongly disagree) to 5 (strongly agree). 
The TAM questionnaire has been validated through the Item Objective Congruence (IOC) Index procedure. Three experts were asked to determine the content validity scores. The results and suggestions were received and the questionnaire has been accordingly revised.

The criterial for interpreting the mean scores are as follows:

1.00 to $1.50 \quad$ Strongly disagree/ very low

1.51 to $2.50 \quad$ Disagree/ low

2.51 to $3.50 \quad$ Nether agree nor disagree/ moderate

3.51 to $4.50 \quad$ Agree/ high

4.51 to $5.00 \quad$ Strongly agree/ very high

\section{Reflective statements}

At the end of the TAM questionnaire, participants were asked to reflect their thoughts about this online learning experience. A prompt of "Benefits" and "Challenges" was given to elicit data for an analysis.

\subsection{Pedagogical design and procedures}

The study adopted a case study approach to assess the effectiveness of optimizing the virtual classroom in Intensive English course to promote collaborative and active learning, enhancing students to successfully accomplish course objectives. In designing the instructional program, The ASSURE instructional model and the Connected Learning model were applied.

The course was designed to be synchronous activity-based instruction that employed additional supportive technological tools and applications to facilitate collaborative and active learning. The use of technological tools and applications was integrated to optimally support the capability of the video meeting platform, Google Meet.

The course was organized following the Pre-While-Post instructional design as shown in Table 4.

Table 4. Struture of the Pre-While-Post Instructional Plan

\begin{tabular}{|c|c|c|c|}
\hline & Pre teaching & While teaching & Post teaching \\
\hline Activities & $\begin{array}{ll}\text { - } & \text { Ice breaking } \\
\text { - } & \text { Prview previous } \\
& \text { lessons } \\
\text { - } & \text { Small talk }\end{array}$ & $\begin{array}{ll}\text { - } & \text { Introduce a new lesson } \\
\text { - } & \text { Ask questions to check } \\
\text { students' knowledge } \\
\text { - } \quad \text { Summarize and share } \\
\text { what was learner } \\
\text { - } \quad \text { Practice/ Do exercise }\end{array}$ & $\begin{array}{ll}\text { - } & \text { Quiz } \\
\text { - } & \text { Exit ticket }\end{array}$ \\
\hline Tecnological Tools & $\begin{array}{ll}- & \text { Google Meet } \\
- & \text { Padlet } \\
- & \text { ClasssDojo }\end{array}$ & $\begin{array}{ll}- & \text { Youtube } \\
- & \text { Padlet } \\
- & \text { Liveworksheets } \\
- & \text { Gamilab } \\
- & \text { Flipping }\end{array}$ & $\begin{array}{ll}- & \text { Kahoot } \\
- & \text { Quizizz } \\
- & \text { Google Form }\end{array}$ \\
\hline
\end{tabular}

The course lasts 3 weeks: 3 hours daily, Monday to Friday, totaling 45 class hours.

\section{Findings and Discussion}

\subsection{Findings}

The results of the study are presented in three parts: analysis of students' accomplishments, TAM questionnaire results, and analysis of students' reflective statements. Because the proficiency level was determined by the adaptive test score, there was no exact score available for each student. The results for this part are thus to report the accomplishment of students from each level based on their post-test score and total course scores. According to the criterial of this post-test, a score of 60 to 80 is considered an A2 level. Additionally, to the cut-off point for an S grade in this course is 59.50 . 
Table 5. A Summary of Students' Accomplishments

\begin{tabular}{cccc}
\hline English Proficiency Level & No. & Post-test* $\mathbf{M ~ ( 1 0 0 )}$ & Total course M (100) \\
\hline Beginnner & 38 & 62.17 & 78.38 \\
A1 & 15 & 73.51 & 83.52 \\
A2 & 8 & 80.33 & 86.85 \\
B1.1 & 2 & 82.77 & 85.15 \\
Total & 63 & $\mathbf{6 7 . 8 3}$ & $\mathbf{8 0 . 8 9}$ \\
\hline
\end{tabular}

a. $*$ The post-test score is also a part, accounting for $25 \%$, of the total course score.

Table 5 shows that all of the students passed both of the criteria. The mean scores of the posttest reveal that although all of them have passed, the amount of their improvements appeared to be related to their initial levels of proficiency before the class. The mean score of the Beginner was 62.17, followed by the A1 (73.51), A2 (80.33), and B1.1 (82.77), respectively. The results of total course mean scores were also similar except for the reverse results between the A2 86.85) and the B1.1 (85.15). The results confirmed that all of the students (100\%) have achieved the overall objectives of the Intensive English course based on both the post-test scores and the total course scores. The results of TAM questionnaire in Table 6 revealed that participants rated at the "Agree" level (4.00 to 4.40) in all four components of the TAM. The highest ranking was "Perceived Ease of Use" $(\mathrm{M}=4.34)$, "Perceived usefulness" $(\mathrm{M}=4.27)$, and "Intention to use" $(\mathrm{M}=4.00)$.

Table 6. Results of TAM questionnaire

\begin{tabular}{|c|c|c|}
\hline & Mean & Meaning \\
\hline Perceived Usefulness & 4.27 & Agree \\
\hline $\begin{array}{l}\text { 1. It enables learners to interact with the instructor and other learner like in } \\
\text { a real classroom. }\end{array}$ & 4.11 & Agree \\
\hline $\begin{array}{l}\text { 2. It is not boring as learners can work in small groups discuss, and play } \\
\text { games. }\end{array}$ & 4.42 & Agree \\
\hline $\begin{array}{l}\text { 3. It keeps all learners alert and attentive as class can be monitored by the } \\
\text { instructor. }\end{array}$ & 4.21 & Agree \\
\hline 4. It is flexible and can be adjusted to situation. & 4.34 & Agree \\
\hline Perceived Ease of Use & 4.40 & Agree \\
\hline 5. It is not complicated to enter the classroom. & 4.53 & $\begin{array}{c}\text { Strongly } \\
\text { agree }\end{array}$ \\
\hline 6. Classroom arrangement is clear and understandable. & 4.48 & Agree \\
\hline 7. It facilitates learners to interact with the instructor and other learners. & 4.24 & Agree \\
\hline 8. The classroom system can be adjusted by the instructor. & 4.35 & Agree \\
\hline Students Satisfaction & 4.34 & Agree \\
\hline 9. It is a virtual classroom that promotes collaborative and active learning. & 4.42 & Agree \\
\hline 10. It is pleasant and fun online learning experience. & 4.35 & Agree \\
\hline 11. It is a virtual clarroom that enhances my academic performance. & 4.26 & Agree \\
\hline 12. Overall, I am satisfied with this online learning experience. & 4.34 & Agree \\
\hline Intention to Use & 4.00 & Agree \\
\hline $\begin{array}{l}\text { 13. I like the virtual classroom that integrates the use of various supportibe } \\
\text { tecjnology tools. }\end{array}$ & 4.34 & Agree \\
\hline $\begin{array}{l}\text { 14. I intend to study to study in the virtual classroom that uses additional } \\
\text { supportive technology tools. }\end{array}$ & 4.15 & Agree \\
\hline $\begin{array}{l}\text { 15. I will attend the virtual classroom that can effectively enhance my } \\
\text { academic performance. }\end{array}$ & 3.92 & Agree \\
\hline $\begin{array}{l}\text { 16. In the future, I would like to attend the virtual classroom that employs a } \\
\text { variety of technology tools to support. }\end{array}$ & 3.61 & Agree \\
\hline
\end{tabular}


Considering the details of the four components of the TAM, it was found that the highest mean score in each component tended to be the key characteristic of the component. In "Perceived Usefulness", it was Q2 "It is not boring as learners can work in small groups, discuss, and play games" $(\mathrm{M}=4.42)$. In "Perceived Ease of Use", it was Q5 "It is not complicated to enter the classroom" (M $=4.53$ ). For "Student Satisfaction", it was Q9 "It is online learning that promotes collaborative and active learning" $(\mathrm{M}=4.42)$. And in the last component "Intention to use", it was Q13 "I like online learning that integrates the use of various supportive technology tools" $(M=4.34)$.

The results of the TAM questionnaire thus revealed that the participants in this study found this online learning program useful, motivating, and practical for the situation. Overall, they were satisfied with this pleasant online learning experience as it promoted collaborative and active learning, and they expected to experience future enjoyable virtual classrooms similar this one.

\section{Reflective statements}

To find out more about the benefits and challenges of online learning in this virtual classroom, students were also asked to write reflective statements about their online learning experiences, at the end of the TAM questionnaire. It was guided with the term "benefits and challenges" as a prompt, and students could feel free to write only one word to very long sentence in response to the prompt. It was anticipated that these reflective statements could be considered salient responses because they would reflect students' distinct perceptions. The reflective statements from all 63 students can be summarized as follows:

\section{Benefits}

The first substantial benefit, which was revealed by 27 reflective statements $(42.9 \%)$, was "The use of various support technology tools and applications effectively promoted interactions between learners and instructor and other learners almost like in a real classroom". The second benefit, "It was pleasant and fun experiences", was overtly addresses by 20 students (31.7\%). Thirdly, 18 students (28.6\%) appreciated "Its ease of use", Interestingly, the fourth benefit which was enjoyed by 16 students $(25.4 \%)$ was "The instructor was nice and kind". Additionally, six students $(9.5 \%)$ simply stated that "It was a very good online learning experience".

\section{Challenges}

While 17 students $(27.0 \%)$ reported that "They did not experience any problems", 23 students (36.5\%) raised an inevitable issue of "Internet unstableness". Secondly, eight students $(12.7 \%)$ revealed that "If possible, they would prefer a real classroom because it would be easier to get to know one another". Thirdly, seven students (11.1\%) had "some difficulties following the lessons". Finally, three students (4.8\%) used "only one device (a mobile or a tablet), resulting in insufficient capability to effectively participate in class".

\subsection{Discussion}

This instructional program of exclusive online teaching for these two Intensive English sections (63 first-year students) has been proven to be successful. The results of both the post-test scores and the total course scores revealed that all of the students (100\%) have achieved the overall objective of the course and the target A2 level.

This success of the implementation of the instructional program is evidently supported by previous studies. Constructing college online learning community that was fully combined with network environment, learners, teachers, and learning resources, Zhang (2020) found that English learners' competences were developed and their English online performances were promoted. Hernandez's revealed that online learning alternative method could improve students' academic performance and enhance their productivity in general. Online learning also provides students with many new opportunities that attract attention and increase their interest and motivation (Valeeva \& Kalimullin, 2021).

The findings from the TAM questionnaire supported that the participants enjoyed opportunities to work in small groups, discuss, play games, and interact with instructor and other learners, almost like in a real classroom. They found it convenient and easy to enter the classroom and to communicate 
with instructor and other learners. They agreed that the integration of various appropriate supportive technology tools and applications helped promote collaborative and active learning. Overall, participants were satisfied with this pleasant online learning experience and were willing to participate in future online learning similar to this one. These TAM questionnaire results are consistent with recent preview research. Rojabi (2020) found that online learning via Microsoft Teams could effectively promote interaction between learners and instructor and other learners. Online class via Microsoft Teams optimally supported students' learning environment. Alfadda and Mahdi (2021) investigated the relationship between the variables of TAM on using Zoom application in language learning. The results revealed that there was "a strong positive correlation between the actual use of Zoom and the students' attitudes and behavioral intention" (p.883).

The reflective statements by students did confirm their satisfaction with this online learning experience. Interestingly, one fourth (25.4\%) of the participants particularly addressed the benefit of having learned with a nice, kind, caring instructor. This reflection could help emphasize that instructor's personal characteristics were one of the key contributing factors. Not unexpectedly, internet unstableness was reported to occasionally be a frustrating experience by 23 participants (or $36.5 \%$ ). Additionally, eight participants (or 12.7\%) preferred a real face to face classroom, so that they could easily get to know one another. The findings are in line with previous students which found that internet unstableness was an inevitable problem and many students would like to go back to real classrooms as soon as possible for various reasons (Cranfield et al., 2021; Sevy-Biloon, 2021).

\section{Conclusion}

The results and discussion have provided evidence to show that integrating various supportive technological tools and applications into online teaching via Google Meet could optimally support the students' learning environment in the virtual classroom. All of the participants were able to achieve the overall objective of the course and the target CEFR' s A2 level. The results from the TAM questionnaire revealed that the participants were aware of the usefulness, satisfied, and willing to participate in future similar online learning. Additionally, participants' satisfaction with this online learning experience has been affirmed in their final reflective statements.

This study has some limitations that might be addressed in future studies. Firstly, Intensive English is a compact three-week course, which is offered before the regular semester starts. The future study may experiment this online instructional program on a course offered in a regular semester. Secondly, it might be interesting to explore on using other learning platform such as Zoom or Microsoft Teams. Thirdly, the findings of this study were based on questionnaire and reflective statement data. Future studies may include interview data. Lastly, because this study used the different types of pre-test and post-test, the future study may use the same type of test for comparative purposes.

\section{Acknowledgment}

The author expresses her gratitude to the School of Liberal Arts, Mae Fah Luang University and the three experts who were reviewers of the TAM questionnaire.

\section{REFERENCES}

Ahshan, R. (2021). A framework of implementing strategies for active student engagement in remote/online teaching and learning during the COVID-19 pandemic. Education Sciences, 11(9). https://doi:10.3390/educsci11090483

Alfadda, H. A., \& Mahdi, H. S. (2021). Measuring students' use of Zoom application in language course based on the Technology Acceptance Model (TAM). Journal of Psycholinguistic Research, 50(4), 883-900. https://doi:10.1007/s10936-020-09752-1

Aljaafreh, A., Alabadleh, A., Alja'Afreh, S., Alaqtash, M., \& Abukhait, J. (2021, June). A questionnaire study on the practice of teaching strategies and technology tools in Jordanian engineering teaching. In 2021 International e-Engineering Education Services Conference (e-Engineering)(pp. 43-48). IEEE. https://doi.org/10.1109/e-engineering47629.2021.9470542

Azimi, S., \& Fazelian, P. (2013). New trends and approaches in instructional design and technology. ProcediaSocial and Behavioral Sciences, 82, 525-528. doi: https://doi.org/10.1016/j.sbspro.2013.06.303 
Bajracharya, J. R. (2019). Instructional design and models: ASSURE and Kemp. Journal of Education and Research, 9(2), 1-9. https://doi.org/10.3126/jer.v9i2.30459

Baldwin, S. J., \& Ching, Y. H. (2020). Guidelines for designing online courses for mobile devices. TechTrends, 64(3), 413-422.

Boonmoh, A., Jumpakate, T., \& Karpklon, S. (2021). Teachers' perceptions and experience in using technology for the classroom. Call-Ej, 22(1), 1-24.

Chaiyo, Y., \& Nokham, R. (2017). The effect of Kahoot, Quizizz and Google Forms on the student's perception in the classrooms response system. 2017 International Conference on Digital Arts, Media and Technology (ICDAMT); ISBN 9781509052103. https://doi.org/10.1109/icdamt.2017.7904957

Cranfield, D., Tick, A., Venter, I. M., Blignaut, R. J., \& Renaud, K. (2021). Higher education students' perceptions of online learning during COVID-19-A comparative study. Education Sciences, 11(8), 403. http://dx.doi.org/10.3390/educsci11080403

Davis, F. D. (1989). Perceived usefulness, perceived ease of use, and user acceptance of information technology. MIS quarterly, 319-340. http://dx.doi.org/10.2307/249008

Dellos, R. (2015). Kahoot! A digital game resource for learning. International Journal of Instructional technology and distance learning, 12(4), 49-52

DeWitt, D., Alias, N., Ibrahim, Z., Shing, N. K., \& Rashid, S. M. M. (2015). Design of a learning module for the deaf in a higher education institution using Padlet. Procedia - Social and Behavioral Sciences, 176, 220-226. http://dx.doi.org/10.1016/j.sbspro.2015.01.464

Heinich, R., Molenda, M., \& Russell, J. D. (1989). Instructional media and the new technologies of instruction. Macmillan.

Hernandez, R. M. (2021). Employing Technology Acceptance Model (TAM): An analysis on students' reception on online learning platforms during covid-19 pandemic. 2021 IEEE International Conference on Automatic Control \& Intelligent Systems (I2CACIS), Automatic Control \& Intelligent Systems (I2CACIS), $2021 \quad$ IEEE International Conference On, 58-63. https://doiorg.proxy.library.mfu.ac.th/10.1109/I2CACIS52118.2021.9495865

Hwang, W.-Y., Shih, T. K., Ma, Z.-H., Shadiev, R., \& Chen, S.-Y. (2016). Evaluating listening and speaking skills in a mobile game-based learning environment with situational contexts. Computer Assisted Language Learning, 4, 639. http://dx.doi.org/10.1080/09588221.2015.1016438

Icard, S. B. (2014). Educational technology best practices. International Journal of instructional technology and distance learning, 11(3), 37-41.

Ito, M., Arum, R., Conley, D., Gutiérrez, K., Kirshner, B., Livingstone, S., ... \& Watkins, S. C. (2020). The connected learning research network: Reflections on a decade of engaged scholarship. Connected Learning Alliance: Irvine, CA, USA.

Johnson, M., Riel, R., Germain-Froese, B., Canadian Teachers' Federation, \& MediaSmarts (Canada). (2016). Connected to learn: Teachers' experiences with networked technologies in the classroom. Canadian Teachers' Federation.

Jusas, V., Butkiene, R., Venčkauskas, A., Burbaite, R., Gudoniene, D., Grigaliūnas, Š., \& Andone, D. (2021). Models for administration to ensure the successful transition to distance learning during the pandemic. Sustainability, 13(9), 4751. http://dx.doi.org/10.3390/su13094751

Kannan, J., \& Munday, P. (2018). New trends in second language learning and teaching through the lens of ICT, networked learning, and artificial intelligence. Círculo de Lingüística Aplicada a La Comunicación; Vol. 76 (2018): Vías de Transformación En La Enseñanza de Lenguas Con Mediación Tecnológica. http://dx.doi.org/10.5209/CLAC.62495

Karakis, H., Karamete, A., \& Okcu, A. (2016). The effects of a computer-assisted teaching material, designed according to the ASSURE instructional design and the ARCS Model of motivation, on students' achievement levels in a Mathematics lesson and their resulting attitudes. European Journal of Contemporary Education, 15(1), 105-113. 
Khamprem, K., \& Boonmoh, A. (2019). Teachers' stated needs and their actual use of technology. Human Behavior Development \& Society, 20(4), 41-51.

Lim, C. P., \& Chai, C. S. (2008). Rethinking classroom-oriented instructional development models to mediate instructional planning in technology-enhanced learning environments. Teaching and Teacher Education, 24(8), 2002-2013. http://dx.doi.org/10.1016/j.tate.2008.05.004

Morrison, G. R., Ross, S. J., Morrison, J. R., \& Kalman, H. K. (2019). Designing effective instruction. John Wiley \& Sons.

Nurpandi, F., Langi, A. Z., \& Bandung, Y. (2013, November). Using instructional design model to implement open lesson with lesson study approach for online teacher community. In 2013 Joint International Conference on Rural Information \& Communication Technology and Electric-Vehicle Technology $(r I C T \& I C e V-T)($ pp. 1-4). IEEE.

Putri, N. S. (2019). Kahoot application in English Language Teaching (ELT) Context: An Alternative Learning Strategy. Elsya : Journal of English Language Studies; Vol. 1 No. 1 (2019): Elsya : Journal of English Language Studies; 11-15; 2684-9224; 2684-7620; 10.31849/Elsya.V1i1. http://dx.doi.org/10.31849/elsya.v1i1.2488

Reinders, H., \& Wattana, S. (2015). Affect and willingness to communicate in digital game-based learning. ReCALL, 27(1), 38-57. http://dx.doi.org/10.1017/S0958344014000226

Rojabi, A. R. (2020). Exploring EFL students' perception of online learning via Microsoft Teams: University level in Indonesia. English Language Teaching Educational Journal,3(2), 163-173. http://dx.doi.org/10.12928/eltej.v3i2.2349

Sanga, M. W. (2019). Doing Instruction design for distance education: An analysis of design and technological issues in online course management. Quarterly Review of Distance Education, 20(1), 35-54.

Sevy-Biloon, J. (2021). Virtual or face to face classes: Ecuadorian university students' perceptions during the pandemic. English Language Teaching Educational Journal, 4(1), 15-24. http://dx.doi.org/10.12928/eltej.v4i1.3935

Sezer, B., Karaoglan Yilmaz, F. G., \& Yilmaz, R. (2013). Integrating technology into classroom: The learnercentered instructional design. Online Submission, 4(4), 134-144.

Valeeva, R., \& Kalimullin, A. (2021). Adapting or Changing: The COVID-19 Pandemic and teacher Education in Russia. Education Sciences, 11(8), 408. http://dx.doi.org/10.3390/educsci11080408

Wang, H., Liu, H., Lu, Z., \& Zheng, C. (2020). Exploring English language learners' conceptions of and engagement in a virtual reality learning environment. In H.J. So et al. (Eds.) Proceedings of the $28^{\text {th }}$ International Conference on Computers in Education. Asia-Pacific Society for Computers in Education.

Weng, F., Yang, R. J., Ho, H. J., \& Su, H. M. (2018). A TAM-based study of the attitude towards use intention of multimedia among school teachers. Applied system innovation, 1(3), 36. http://dx.doi.org/10.3390/asi1030036

Wong, S. Y., Tee, W. J., \& Jasman, M. A.A. B. (2015). 2D Side-Scrolling Game: Applying Motivation and Digital Game-Based Learning (DGBL) in English learning. Springer Singapore. http://dx.doi.org/10.1007/978-981-287-399-6_32

Zain, I. M. (2018). The Collaborative Instructional Design System (CIDS): An Innovative Instructional Design Tool for the 21st Century Learning. https://doi.org/10.13189/ujer.2017.051216

Zhang, J. (2020). The construction of college english online learning community under ADDIE Model. English Language Teaching, 13(7), 46-51. http://dx.doi.org/10.5539/elt.v13n7p46 


\section{APPENDIX}

\section{Intensive English}

\section{Course Description}

Foundations of contextualized English grammar, vocabulary, and structures essential to conduct everyday transactions involving familiar situations and topics; intensive practice of basic English language functions; preparation of study skills for effective pursuit of English-medium studies; and introduction to and encouragement of self-directed learning through the use of technological aids.

\section{Course Objectives}

After the completion of this course, students will be able to:

1. achieve all 4 English skills at A2 level in accordance with the Common European Framework of Reference for Languages (CEFR) with the use of technological aids;

2. speak English using appropriate and accurate vocabulary and expressions in daily life or familiar situations or topics;

3. identify main ideas, specific information, facts and opinions in English reading passages and video or audio clips;

4. write complete English sentences using various sentence structures with grammatical accuracy;

5. develop self-directed learning skills.

\section{Course Content}

\begin{tabular}{|c|c|c|}
\hline No. & Topic & Brief content \\
\hline 1. & $\begin{array}{l}\text { - Ice-breaking } \\
\text { - Introducing course materials } \\
\text { - Getting to know your teacher and classmates }\end{array}$ & $\begin{array}{l}\text { Grammar review: Present Simple } \\
\text { (statement, negation, question), Present } \\
\text { Continuous, Present Continuous for the future }\end{array}$ \\
\hline 2 & Life Events & $\begin{array}{l}\text { Sports, Leisure time, Expressions of time Past } \\
\text { Simple (statement, negative, question) }\end{array}$ \\
\hline 3 & Clothes and Accessories & $\begin{array}{l}\text { Clothing } \\
\text { Past Simple (regular/irregular verbs) }\end{array}$ \\
\hline 4 & Possibility and Necessity & $\begin{array}{l}\text { Modal verbs (possibility, intention, obligation } \\
\text { and necessity), Would like, Want }\end{array}$ \\
\hline 5 & Air Travel & $\begin{array}{l}\text { Airports, on the plane } \\
\text { Indirect questions } \\
\text { Writing Test } 1\end{array}$ \\
\hline 6 & Quantity & $\begin{array}{l}\text { Expressing quantity, Quantifiers, Count and } \\
\text { Non Count nouns }\end{array}$ \\
\hline 7 & Have you ever? & $\begin{array}{l}\text { Talking about literature } \\
\text { Present Perfect (statement, negative, question) }\end{array}$ \\
\hline 8 & How often? & $\begin{array}{l}\text { Daily routines, Animals } \\
\text { Adverbs (of frequency, of time) }\end{array}$ \\
\hline 9 & All by myself & $\begin{array}{l}\text { Car parts } \\
\text { Reflexive pronouns, adjectives and adverbs }\end{array}$ \\
\hline 10 & In my opinion & $\begin{array}{l}\text { Expressing opinion, } \\
\text { Adverb of manner, Comparison of adverbs, } \\
\text { gerunds and infinitives } \\
\text { Writing Test } 2\end{array}$ \\
\hline 11 & Let's go surfing! & $\begin{array}{l}\text { Water sports } \\
\text { Present Perfect vs. Past Simple }\end{array}$ \\
\hline 12 & Asking for refund & $\begin{array}{l}\text { Shopping } \\
\text { Electronic devices } \\
\text { If-Clause (zero conditional) }\end{array}$ \\
\hline 13 & That is fascinating! & $\begin{array}{l}\text { Expressing how you feel, Banking } \\
\text { Participles as adjectives }\end{array}$ \\
\hline 14 & REVIEW & $\begin{array}{l}\text { REVIEW } \\
\text { Speaking Test }\end{array}$ \\
\hline 15 & READ ALOUD Performance & READ ALOUD Performance \\
\hline
\end{tabular}




\section{Assessment}

Self-study (Online Course Completion + Final Test) 50\% 2 Writing test (x2) 20\% 3 Show \& Tell 5\% 4 Read Aloud (Group Live Performance) 15\% 5 Speaking test 10\% Total 100\%

\section{Grading Scale}

S $59.50-100$

U $0-59.49$ 